\title{
CO2 laser myringoplasty using handheld waveguide
}

\author{
David Kaylie*, Jason Miller \\ From 2nd Scientific Meeting of the Head and Neck Optical Diagnostics Society \\ San Francisco, CA, USA. 23-24 January 2010
}

\section{Introduction}

Eustachian tube dysfunction is very common and is the predominant cause of otitis media with effusion. Negative middle ear pressure generated by Eustachian tube dysfunction can cause deformation of the collagen layer in the ear drum. Collagen becomes stretched and looses its orderly array. Over time, deep retraction pockets form. If left untreated, the tympanic membrane becomes prone to cholesteatoma formation. CO2 laser energy interacts with collagen and causes it to return to its natural configuration.

\section{Objective}

To describe and review our results treating tympanic membrane retraction pockets using laser myringoplasty with a novel hand-held flexible photonic band gap fiber $\mathrm{CO} 2$ laser.

\section{Methods}

A hand-held flexible fiber $\mathrm{CO} 2$ laser system (Omniguide BeamPath) was used to treat tympanic membrane retraction pockets. The fiber tip was held approximately $3 \mathrm{~mm}$ from the membrane surface producing a spot size of 570 microns at the setting of 2 watt per 100 millisecond pulse. Pulses were administered until the desired level of membrane contraction was achieved. A tympanostomy tube was then placed in the affected ear.

\section{Results}

We reviewed our results with this procedure on 22 patients (40 ears). The average pre-operative air bone gap (ABG) pure-tone average (PTA) was $15 \mathrm{~dB}$. The average post-operative ABG PTA was $6 \mathrm{~dB}(\mathrm{p}=0.002)$. All patients had satisfactory contraction of the atelectatic segment. There were no adverse events recorded.

Duke University Medical Centre, Durham, USA

\section{Conclusion}

Laser myringoplasty using the Omniguide hand-held flexible fiber $\mathrm{CO} 2$ laser provides immediate hearing improvement and eardrum contraction. Long-term results are pending.

Published: 29 October 2010

doi:10.1186/1758-3284-2-S1-032

Cite this article as: Kaylie and Miller: $\mathrm{CO} 2$ laser myringoplasty using handheld waveguide. Head \& Neck Oncology 2010 2(Suppl 1):O32.
Submit your next manuscript to BioMed Central and take full advantage of:

- Convenient online submission

- Thorough peer review

- No space constraints or color figure charges

- Immediate publication on acceptance

- Inclusion in PubMed, CAS, Scopus and Google Scholar

- Research which is freely available for redistribution

Submit your manuscript at www.biomedcentral.com/submit
C Biomed Central 